\title{
The Moderating Role of Self-Control in the Relationship between Peer Affiliation and Adolescents Antisocial Behavior in Tehran, Iran
}

\author{
Roya Kavian Mobarake ${ }^{1}$, Rumaya Juhari ${ }^{2}$, Siti Nor Yaacob ${ }^{2} \&$ Nooshin Sabour Esmaeili $^{2}$ \\ ${ }^{1}$ Faculty of Human Ecology, University Putra Malaysia, Malaysia \\ ${ }^{2}$ Family, Adolescent and Child Research Centre (FACE), Universiti Putra Malaysia, Malaysia \\ Correspondence: Rumaya Juhari, Family, Adolescent and Child Research Centre (FACE), Universiti Putra \\ Malaysia, Malaysia. E-mail: rumaya@upm.edu.my
}

Received: October 19, 2013 Accepted: March 12, 2014 Online Published: April 29, 2014

doi:10.5539/ass.v10n9p71

URL: http://dx.doi.org/10.5539/ass.v10n9p71

\begin{abstract}
This study aims to examine the moderating effect of self-control in the relationship between peer affiliation and antisocial behavior in a sample of 395 adolescents aged 13 to 18 years old in Tehran city in Iran. Inventory of Parent and Peer Attachment (IPPA; Armsden \& Greenberg, 1987), Self-Control Scale (Grasmick et al., 1993) and modified of Antisocial Behavior scale (Dekovic, 1999) were utilized to measured peer affiliation, self-control and antisocial behavior, respectively. Results of this study indicated that peer affiliation was significantly related to antisocial behavior among adolescents. The findings of this study have important implications that address the moderating role of self-control in the relationship between peer affiliation and adolescent's antisocial behavior.
\end{abstract}

Keywords: peer affiliation, antisocial behavior, adolescent, self-control

\section{Introduction}

Adolescence is the stage of human development that is associated with changes in different areas. Adolescent changes not just physically, but also socially, behaviorally, cognitively, morally and in social relations with others (Rezayi, Kharazi, Hejazi \& Afrooz, 2007). Santrock, (1996) believed that adolescence time is started at the age of seven years and extend up to 18-22 years old. Meanwhile, Peterson (2004) consider adolescence period between 12 and 18 years old from completion of primary school to graduation from high school. Early adolescence is the time for the most pubertal changes and differs to the late adolescence. According to Sussman (2013), important behavioral patterns affecting whole life span, is formed during adolescence period. To have a healthy society and to control high risk behavior, antisocial behavior and delinquent actions of adolescents must be taken into consideration (Rezayi et al., 2007).

Antisocial behavior is manifested and developed during early adolescence and is a stern worry to society (Wright, John, Livingstone, Shepherd \& Duku, 2007). Bonino, Cattelino and Ciairano (2005), Sobotkova, Blatny, Jelinek, and Hrdlic (2012) defined antisocial behaviors as behaviors that breach norms, values, and principles accepted or recognized by the particular society. According to the National Center for Education Statistics of USA (2010) more than 60 percent of children in the United States of America were showing directly (e.g., victims) and indirectly (e.g., witnesses) violence to people around them. National Center for Education Statistics of USA (2007) reported that 75 percent of public schools faced with at least one event of violent crime during the 2007 to 2008. Iran, also reported an increasing number of cases involving antisocial behavior. Mohammadiasl (2006) revealed that 28,000 children and adolescents were sent to correction and rehabilitation centers which makes a worrying concern among Iranian society. In order to reduce adolescent's antisocial behaviors, the Iranian government has devised and employed several ways, including, establishment and administration of juvenile justice, remand homes, security and law enforcement agency, and promulgation of juvenile laws and courts (Mohammadiasl, 2006). Due to the high rate of adolescents antisocial behavior in Iran (Mohammadiasl, 2006; Ardalan, Iravani \& Sobhi-Gharamaleki, 2010) and consequences of adolescents antisocial behavior in family and community, It is important to study what factors contributes to adolescents antisocial behavior.

Peer group is one of the strongest factors that linked to adolescents antisocial behaviors. Peer group provides a training ground for antisocial behavior as peers often supply the adolescent with the attitudes, motivations, and 
rationalizations support antisocial behavior and provide opportunities to engage in specific delinquent acts (Patterson, Dishion \& Yoerger, 2000). Adolescents who were involved in antisocial behavior tend to relate with other antisocial adolescents and the new groups would go through offensive actions together (Mrug, Hoza \& Bukowski, 2004; Dishion \& Patterson, 2006).

Evidence suggests that deviant peers are more influential in the development of covert behavior than overt behavior, possibly because covert acts such as shoplifting and vandalism may be more likely to be committed by a group (Brendgen, Vitaro \& Bukowski, 2000). Some evidence suggests that parenting has more of an influence on overt than covert antisocial behavior, although the possible reasons for this differential effect are unclear (Hinshaw et al., 1997; Gorman-Smith \& Loeber, 2005). Several studies have documented that the adolescent's antisocial behavior is correlated with the antisocial behavior and delinquent acts of peer group (Baerveldt \& Snijders, 1994; Golchin, 2008). Some studies focus on quality of peer affiliation and others worked on a different kind of deviant behavior. Demuth (2004) concluded that despite not having any peers, adolescence involves in antisocial and delinquent behavior. Prior to Demuth's research there did not exist any study on adolescence who accounted that they had no friends. Demuth's study fills the gap in research considering the affiliation of adolescence peer delinquency and associations Youths' friendships have been of interest to many researchers exploring antisocial behaviours of young people. Dishion, Nelson and Yasui's (2004) were interested in determining whether individual risks for maladaptation would be amplified by friendship dynamics that were organized around deviance. They found differences between adjusted and antisocial youths in terms of their friendship dynamics such that those who are well adjusted have 'known friendships' longer, and that antisocial youths tend to spend more time with their friends.

Research by Brook, Brook, Balka, and Rosenberg (2006) examined the predictors of antisocial behavior of adolescents in a singular model. They gathered a sample of biological children of African American and Puerto Rican adolescents who participated through a longitudinal study to assess the implications of antisocial behavior and peer affiliations of adolescents. They found a significant relationship between antisocial behavior and peer affiliations/social bonds (Brook et al., 2006). Consequently, adolescents are engaging in antisocial behavior as a result of weak social bonds with peers. Similarly, Hirschi (1969), who offered social control theory, also confirmed that an adolescent engages in antisocial behavior to cope with stress or as a result of weak bonds with others. A major gap in the current literature is the ambiguity in the causal relationship between social networks and antisocial behavior (Houtzager \& Baerveldt, 1999). Some researchers have concluded that a relationship exists between an adolescent's antisocial behavior and the antisocial behaviors of the peer group, but not necessarily a causal effect (Moss et al., 2003). Vitaro et al. (2000) believe that deviant peer was related to higher level of antisocial behavior in comparison to non- deviant peer. Bernburg, Krohn and Rivera (2006) explored that adolescents who publicly labeled negatively are more associated with deviant peers. In addition, such researches indicate that, during adolescence, antisocial behavior is positively associated with peer acceptance. The current study hypothesizes that there is a direct and significant relationship between peer affiliation and adolescent's antisocial behavior.

On the other hand, self-control can be described as the individual's ability to manage his or her desires, disrupt undesired behavioral leanings, change his or her feelings and consideration, and desist from acting on them (Muraven \& Baumeister, 2000). Self-control which is settled through childhood plays a critical role in the expansion of antisocial behavior (Gottfredson \& Hirschi, 1990). All forms of deviant behavior might be illuminated by lack of self-control (Gottfredson \& Hirschi, 1990). In previous studies, self- control is used as a moderator between time perspective and academic achievement (Barber, Bagsby, Grawitch \& Munz, 2009) and as a moderator between victimization and perpetrations (Nobels, Cramer \& Kericher, 2012). Cross-sectional studies on adolescents exposed moderate-to-strong relationship between antisocial behavior and levels of self-control. Vazsonyi, Pickering, Junger, and Hessing (2001) showed that scores on the self-control scale developed by Grasmick, Tittle, Bursik, and Arneklev (1993) accounted for $10 \%-16 \%$ of the variance of adolescent antisocial behavior in Hungary, Netherlands, Switzerland, and the United States. Moreover, Vazsonyi et al. (2004) demonstrated that self-control contribute to delinquent behavior over and outside the power of parenting, emphasized the exclusive descriptive power of low self-control to the growth of delinquent behaviors such as robbery, vandalism and physical attack. This information implies that self-control might be a relevant moderator in the adolescent antisocial behavior studies.

According to the general theory of crime Gottfredson and Hirschi (1990), low self-control in combination with an opportunity is considered to be the only cause of crime, and the level of self-control is presumed to correspond to the mean number of crimes. General theory of crime as one of the most influential theories in criminology has triggered extended research investigating whether low self-control predicts criminal behavior 
(e.g. Vazsonyi et al., 2001; Tittle et al., 2003; Ward et al., 2010; Moffitt et al., 2011). Even though studies (Cretacci, 2008) found that results contradicting minor hypotheses (e.g. Self-control predicts all forms of crime equally well) most of the studies corroborate the main hypothesis that self-control predicts crime. Burt et al. (2006, p. 378) found that low self-control was significantly associated with increased counts of self-reported delinquent acts. Similarly, Baron (2003) found low self-control to be a strong predictor of property crime, violent crime, drug use, and overall street crime.

Evans et al. (1997, p. 493) concluded that the correlations between self-control and crime analogous behaviors were empirically related to criminal and deviant behavior as well as negative experiences in other realms of life. In addition, low self-control was associated to reduce the quality of interpersonal relationships with family and friends, diminished involvement in church, low levels of educational and occupational attainment, and even possible poor marriage prospects. Paternoster and Brame's (1997) found similar effects of self-control on crime and antisocial behaviors. A meta-analysis by Pratt and Cullen (2000) summarized that, across different measures and types of samples, low self-control is an important predictor but not the only predictor of antisocial behavior and delinquent acts. Underpinning the practical relevance of this branch of research, another meta-analysis found that training programs designed to promote self-control among children and adolescents improve self-control and reduce delinquency (Holtfreter, Reisig, Piquero \& Piquero, 2010).

The effects of peer affiliation on antisocial behavior have generally been studied in western countries (Snyder, Edwards, McGraw, Kilgore \& Holton 1994; Patterson et al., 1989; Farrington, 2009). However, there are fewer studies in Iranian context. Results of the past research highlighted above demonstrating a significant relationship between peer affiliation, self-control and adolescents' antisocial behavior. Therefore, this study aimed to examine the moderating role of self-control in the relationship between peer influence and antisocial behavior in adolescents.

\section{Method}

\subsection{Participants}

A total of 395 adolescents' boys and girls recruited from daily high schools in Tehran city in Iran, were involved in this study using cluster sampling method. The participants were between 13 to 18 years old with the mean age of 15 years old $(\mathrm{SD}=1.44)$.

\subsection{Measures}

Peer Affiliation: Inventory of Parent and Peer Attachment (IPPA; Armsden \& Greenberg, 1987) was used to measure peer affiliation including degree of mutual trust; quality of communication; and the amount of anger and alienation. The scale has 25 items on a 5- point Likert scale ranging from "Almost Never or Never True " to "Almost Always or Always True". The total score ranged from 25 to 125 with higher scores indicating higher attachment. The IPPA is scored by reverse-scoring the negatively worded items ( 3 and 9 in parent trust, 6 and 14 in parent communication, and 5 in peer trust) and then summing the response values in each section. In this study the Cronbach's alpha coefficient of the scale was .86 .

Antisocial Behavior: Antisocial behavior assessed by Antisocial Behavior Questionnaire (Dekovic, 1999). The scale has 18 items focused on minor acts such as truancy or using public transportation without paying, as well as more serious deviance such as beating someone on purpose or intentionally setting fires. The adolescent was asked to indicate how frequently occurred within the past last 12 months: $0=$ never, $1=$ once, $2=$ two or three times, 3 = four to ten times and $4=$ more than ten times. Since the study was conducted in Iran, three items were deleted, including 1- Using soft drugs (cannabis), 2- Using hard drugs (heroin, cocaine, LSD, speed) 3 - Being drunk. Seven items were added to the questionnaire including 1-Skipped school without a good excuse, 2-Taken little things worth less than five dollars that did not belong to you, 3- Watching pornography, 4- Trespassed on to people's property, 5- Wear dress or make up opposite of school's rule, 6- Argue with the teacher or school principals, 7- Beating classmates or other students in school. Based on the previous studies and current discipline principles in Iran, seven items have been added to this questionnaire. The total scale ranged from 0 to 88 with higher scores indicating high level of antisocial behavior. Antisocial behavior questionnaire has an overall alpha 0.94 for the total scale (Dekovic et al., 2004). The reliability assessment of the antisocial behavior scale in the present study yielded an alpha coefficient of .79 .

Self-control: Self-control was measured using the 24- items Self-Control Scale (Grasmick et al., 1993). The scale contains four questions for each of six sub-categories, (impulsivity, simple tasks, risk seeking, physical activities, self-centeredness, and temper). Questions pertaining to each sub-component were grouped together, and the response set included ' $1=$ strongly disagree, ' $2=$ disagree somewhat,' ' $3=$ agree somewhat,' and ' $4=$ strongly 
agree'. The scale was scored by a simple total of individual items. The total score ranged from 24 to 96 . A higher score in this scale indicates a higher level of self-control. The results from Grasmick et al. (1993) study shows that the scale has a high level of reliability, with an alpha at 0.80 . Reliability assessment of the self-control scale in the present study yielded an alpha coefficient is 0.70 .

\subsection{Procedure}

The study was approved by the Tehran Department of Education. To select the respondents, a list of students with discipline problems was received from school's counselor. Then all students under the list were participating in the survey.

\subsection{Statistical Analysis}

A descriptive statistical analysis (frequency, percentage, means and standard deviations) was conducted to describe the variables of the study. Pearson's Product-moment Correlation Coefficient was used to determine the direction and strength (negative or positive) of the linear relationship between dependent variables and independent variables. A Pearson correlation analysis was conducted to determine the association between peer affiliation and adolescents' antisocial behavior. A hierarchical multiple regression analyses were conducted to test the moderating role of self-control in the relationship between peer affiliation and adolescents' antisocial behavior. Hierarchical multiple regression analysis is a more useful technique on moderating analysis. Hierarchical multiple regression analyses examine whether an interaction between two variables (one independent variable and a moderator) is a significant predictor of an outcome variable, after controlling for the effect of the two predictors. The presence of a significant interaction tells us that there is significant moderation (the association between the predictor and the outcome is significantly different across levels of the moderator or that the association is conditional on values of the moderator), but it shows little about the specific conditions that dictate whether the predictor is significantly related to the outcome.

\section{Results}

All the measures used in this study had acceptable reliabilities ranging from .70 to .93 . Based on the group mean score displayed in Table 1, all study variables were categorized into high and low. As seen in Table 1, majority $(61.1 \%)$ of respondents reported high level of peer affiliation. A total of $50.4 \%$ of respondents were in the low level category of self-control. Table 1 also showed that majority $(53.5 \%)$ of respondents had antisocial behavior score above the score mean while $46.5 \%$ of respondents had antisocial behavior score below the score mean. The skewness value for all study variables was between -2 and +2 , suggesting no violation of the assumption of normality.

Table 1. Descriptive analysis of peer affiliation, self-control and antisocial behavior

\begin{tabular}{lcccccccc}
\hline Variables & Mean & SD & Min & Max & $\mathbf{n}$ & $\mathbf{\%}$ & Skewness & Reliability \\
\hline Peer affiliation & 2.54 & .39 & 1.40 & 3.51 & 393 & 99.5 & -.577 & .86 \\
Low $\leq 2.54$ & 38.9 & & & & & & & \\
High $>2.55$ & 61.1 & & & & & & & \\
Self-control & 2.68 & .40 & 1.71 & 3.67 & 395 & 100 & .011 & .70 \\
Low $\leq 2.68$ & 50.4 & & & & & & & \\
High $>2.69$ & 49.6 & & & & & & & \\
Antisocial behavior & 20.95 & 9.54 & 0 & 48 & 395 & 100 & .324 & .80 \\
Low $\leq 20.95$ & & & & & & 46.5 & & \\
High $>20.96$ & & & & & & 53.5 & & \\
\hline
\end{tabular}

The Pearson product-moment correlation was used to determine the relationships between peer affiliation and antisocial behavior among adolescents. As seen in Table 2, there was a positive significant correlation between peer affiliation and antisocial behavior $(\mathrm{r}=0.28, \mathrm{p} \leq 0.01)$. This means that higher level of peer affiliation was associated with higher level of antisocial behavior. Past research (Allen, Porter, McFarland, McElhaney \& Marsh, 2007; Dekovic, Noom \& Meeus, 1997; Chung, Hill, Hawkins, Gilchrist \& Nagin, 2002; Kiesner \& Massimiliano, 2005; Bernburg et al., 2006) has found a relationship between peer affiliations and adolescent's antisocial behavior. There are some possible reasons for these findings. First, according to (Hirschi, 1969; Kandel, 1990; Vitaro, 
Tremblay, Kerr, Pagani \& Bukowski, 1997) association with deviant peers is often assumed to influence adolescents to engage in antisocial behavior. On the other hand, studies (Lauru, Padilla-Walker, Roy, Been \& Alexander, 2011) emphasize that adolescents perception of peer expectations for negative behavior were positively related to adolescents antisocial behavior. Second, adolescents with history of antisocial behavior are subjected to suboptimal parenting practices, and feel alienated from conventional socializing agents and settings may be more likely to seek out deviant peers and emulate their behavior. These adolescents may have fewer internalized inhibitions against such behavior and perceive fewer negative (and perhaps more positive) consequences of the deviant behavior (Dishion \& Patterson, 2006).

Table 2. Relationship between peer affiliation, self-control and antisocial behaviour

\begin{tabular}{cc}
\hline Variables & Antisocial behavior $(r)$ \\
\hline Peer -Affiliation & $.28^{* *}$ \\
Self-control & $-.48^{* *}$ \\
\hline
\end{tabular}

As depicted in Table 2, there is a negative significant relationship between self-control and antisocial behavior ( $\mathrm{r}$ $=-0.48, p \leq 0.01)$. This means that as self-control increased the frequency of antisocial behavior decreased. The present finding supports the results of previous studies (Feldman et al., 1994; Kim et al., 2005; Dekemp, Vermulst, Finkenauer, Scholte, Overbeek, Rommens \& Engels, 2009) demonstrating that adolescents with low levels of self-control are more likely tend to exhibit antisocial behavior.

According to Gottfredson and Hirschi (1990) low self-control developed during childhood that plays a crucial role in the development of deviant behavior, such as substance abuse, and antisocial behavior. They indicated that low levels of self-control may predict involvement in a number of self-indulgent behaviors that coincide with crime and deviance such as smoking, drinking, fast driving, and illicit. So, adolescents who have low self-control might lead to poor peer choices, unstable occupational histories, and deficient educational achievement. Heimer and Matsueda (1994) assume that having engaged in delinquent behavior directly affects the way the person is being labeled by others and by him or herself. Appraising oneself as a rule violator from the standpoint of others implies a more antisocial attitude. This means that low level of self-control may predict future deviant behavior of adolescence. On the other hand, Dekemp et al. (2009) illustrated that in early adolescents, higher levels of self-control are associated with less antisocial behavior. Therefore, level of self-control is a one of the strongest predictor of deviant behavior in adolescence.

Hierarchical multiple regression analyses were employed to determine first, predictors of adolescents' antisocial behavior, and second, to examine the moderating role of self-control in the relationship between peer affiliation and dependent or outcome variable. Moderator is a quantitative or qualitative variable that may affect the direction and strength of the association between a predictor or independent variable and criterion or dependent variable (Baron \& Kenny, 1986).

At step 1, three background variables including age, gender of respondents, and family income were entered into the regression analysis. All the three background variables explained 13.2. $\%(\mathrm{R} 2=.13 .2, p \leq 0.05)$ of the variance in adolescents antisocial behavior. At step 2, peer affiliation was entered into the hierarchical regression model. Peer affiliation was statistically significant $(\operatorname{Beta}=.280, p \leq 0.05)$. At step 3, self- control as a moderator was added. Findings from this step showed that self-control $(\beta=-0.38, \mathrm{p} \leq 0.01)$ was negatively associated with adolescents antisocial behavior. This means that higher levels of self-control predicted a lower level of adolescent's antisocial behaviour. The present finding supports the results of previous studies (Feldman et al., 1994; Kim et al., 2005; Dekemp, Vermulst, Finkenauer, Scholte, Overbeek, Rommens \& Engels, 2009) demonstrating that adolescents with low levels of self-control are more likely tend to exhibit antisocial behaviour. All study variables in step 3 were statistically significant, with the self-control is recording higher beta value $(B e t a=-.381, p \leq 0.05)$ than gender (Beta $=-.236, p \leq 0.05)$, peer affiliation (Beta $=.217, p \leq 0.05)$, family income $(B e t a=-.128, p \leq 0.05)$, and finally age (Beta $=.099, p \leq 0.05)$. Self- control emerged as the strongest predictor of adolescents' antisocial behavior. Low self - control contribute to the high level of antisocial behavior among adolescents. Thus, the present research support that the variance of antisocial behavior is highly influenced by self- control. At Step 4 the hierarchical multiple regression analysis for the multiplicative interaction term (peer affiliation $\times$ self-control) was computed. As depicted in Table 3, self-control moderates the relationship between peer affiliation and adolescent's antisocial behavior (Table 3). According to Table 3, the interaction between the peer affiliation and self-control was significant for antisocial behavior $(F(6,386)=34.24, p<0.05)$. The 
moderator effect of self-control was strong enough to make the relationship between peer affiliation and antisocial behavior when self -control was low and conversely. When the interaction variables were significant predictor of the dependent variables, post hoc probing was performed to determine under which condition, the moderator variable is significant. To examine a possible interaction, a plot was created at specific levels of the moderator variables (Aiken \& West, 1991; Holmbeck, 2002; Tabachnick \& Fidell, 2001). The moderator effect of self-control on the relationship of peer affiliation and antisocial behavior is graphically shown in Figure 1 . The Figure shows the predicted relationship between high $(\mathrm{z}=1)$ and low $(\mathrm{z}=-1)$ levels of peer affiliation and antisocial behavior at high $(\mathrm{z}=1)$ and low $(\mathrm{z}=-1)$ levels of self-control. The plot of interaction terms indicated positive influence of peer affiliation on adolescent's antisocial behavior was significant when there is low self-control.

Table 3. Hierarchical regression analysis of the moderating effect of self-control in the influence of Peer affiliation and antisocial behavior

\begin{tabular}{|c|c|c|c|c|c|c|c|c|c|c|c|c|}
\hline \multirow[t]{2}{*}{ Variables } & \multicolumn{3}{|c|}{ Step 1} & \multicolumn{3}{|c|}{ Step 2} & \multicolumn{3}{|c|}{ Step 3} & \multicolumn{3}{|c|}{ Step 4} \\
\hline & B & SE & Beta & B & SE & Beta & B & SE & Beta & B & SE & Beta \\
\hline Age & .045 & .013 & $.159 * *$ & .044 & .013 & $.155^{* *}$ & .029 & .012 & $.104 * *$ & .028 & .012 & $.099 * *$ \\
\hline $\begin{array}{l}\text { Gender (1=Female; } \\
2=\text { Male) }\end{array}$ & -206 & .038 & $-.254 * *$ & -.226 & .037 & $-.279 * *$ & -.198 & .034 & $-.244 * *$ & -.191 & .034 & $-.236^{* *}$ \\
\hline Family Income & .000 & .000 & $-.188 * *$ & .000 & .000 & $-.157 * *$ & .000 & .000 & $-.127 * *$ & .000 & .000 & $-.128 * *$ \\
\hline Peer Affiliation & & & & .290 & .047 & .280 & .213 & .044 & $.206^{* *}$ & .225 & .044 & $.217 * *$ \\
\hline Self-control & & & & & & & -.380 & .044 & $-.375^{* *}$ & -.385 & .043 & $-.381^{* *}$ \\
\hline $\begin{array}{l}\text { peer affiliation } \times \\
\text { Self control }\end{array}$ & & & & & & & & & & -.038 & .017 & $-.095 * *$ \\
\hline Intercept & .729 & .217 & & .016 & .238 & & 1.382 & .268 & & 1.372 & .267 & \\
\hline$R^{2}$ & .132 & & & .209 & & & .339 & & & .347 & & \\
\hline$\Delta R^{2}$ & .132 & & & .077 & & & .130 & & & .009 & & \\
\hline Adjusted $R^{2}$ & .125 & & & .201 & & & .330 & & & .337 & & \\
\hline$F$ & $\mathrm{~F}(3,3$ & $89)=1$ & $9.72 * *$ & $\mathrm{~F}(4$, & $88)=1$ & $5.60 * *$ & $\mathrm{~F}(5,3$ & 87) $=$ ? & $.63 * *$ & $\mathrm{~F}(6$, & $86)=3$ & $4.24 * *$ \\
\hline
\end{tabular}

Note: $* *=0.05, * * *=0.001$

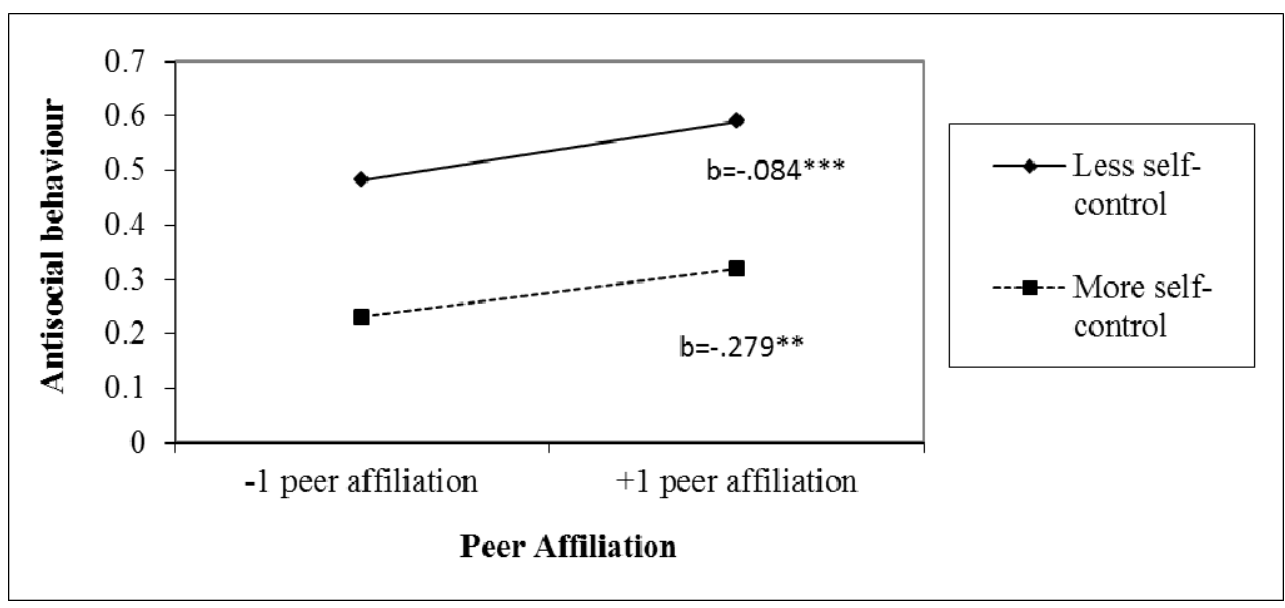

Figure 1. Graphical plot of the interaction between peer affiliation and self-control on adolescent antisocial behaviour, $b$ - unstandardized coefficient (simple slope)

${ }^{* *} \mathrm{p} \leq .0 .01, * * * \mathrm{p} \leq .001$.

This finding is consistent with the previous research (Schrech et al., 2002; Stewart et al., 2004; Fox, 2009) 
indicating stronger association between the peer affiliation and adolescent's antisocial behavior. One explanation for this finding is that low level of self-control strongly associated with several forms of risky behavior and antisocial behavior act. Individuals with low self-control often lead to poor peer choices. Adolescents with low self-control also often make decisions impulsivity, engage in risky behavior and have a higher frequency of exposure to deviant populations that increases their risk of antisocial behavior. Second, according to Gottfredson \& Hirschi (1990), low self-control not only fully explains being part of a deviant peer group but also would predict being part of a central member of a deviant peer group, and being involved with a deviant group. Gottfredson and Hirschi (1990) proposed that individual with low level of self-control is unlikely to make friends with peers who are high in self-control. Because low in self- control gravitate toward one another largely because they are not attractive friends to pro-social individuals, and they are often excluded from conventional ties (Coie, Belding, \& Underwood, 1988; Vitaro, Gagnon, \& Tremblay, 1990). Therefore, the general theory of crime asserts that both having deviant peers and spending ample time with them are fully endogenous to self-control.

\section{Conclusion}

The goal of this research was to examine the moderating effect of self-control in the relationship between peer affiliation and adolescents' antisocial behaviour in Tehran, Iran. The present study found that self-control significantly moderated the relationship between peer affiliation and adolescents' antisocial behavior. Adolescents who experienced higher level of peer affiliation and lower level of self-control indicated a higher level of adolescents' antisocial behaviour.

Findings from this study will be useful for school, and educational counselors, to be more sensitive to the needs of adolescents from unhealthy families. The information from the present study is also important for educators to better understand the factors that may have a crucial influence on the adolescents' antisocial behavior. The results of this study also suggest that parent and peer play a unique and important role in the adolescent's antisocial behavior. So the results are beneficial for parents to be aware and sensitive on how antisocial behaviors contribute to their adolescents.

There are some limitations in conducting this research. First, the respondents of this study were only limited to adolescents aged between 13 and 18 years old in Tehran-Iran and not to the adolescents in other areas. Another limitation in the current study is a cross- sectional study, so it is not possible to examine the long-term effect of peer affiliation on adolescent's behavior problems to better understanding the situation. The findings of this study would be based on self-reported data that may result in some kind of bias.

\section{References}

Aiken, L. S., \& West, S. G. (1991). Multiple regression: Testing and interpreting interactions. Newbury Park: London. Sage.

Allen, J. P., Porter, M., McFarland, C., McElhaney, K. B., \& Marsh, P. (2007). The relation of attachment security to adolescents' paternal and peer relationships, depression, and externalizing behaviour. Child Development, 78, 1222-1239. http://dx.doi.org/10.1111/j.1467-8624.2007.01062.x

Ardalan, D., Iravani, M., \& Sobhi-Gharamaleki, N. (2010). A comparison of the personality characteristics of delinquent and non-delinquent juvenile of Tehran, Iran. International Journal of Criminology and Sociological Theory, 3(1), 372-384.

Armsden, G. C., \& Greenberg, M. T. (1987). The inventory of parent and peer attachment: Individual differences and their relationship to psychological well-being in adolescence. Journal of youth and adolescence, 16(5), 427-454. http://dx.doi.org/10.1007/BF02202939

Baerveldt, C., \& Snijders, T. A. B. (1994). Influences on and from the segmentation of networks: Hypotheses and tests. Social Networks, 16, 213-232. http://dx.doi.org/10.1016/0378-8733(94)90006-X

Barber, K. L., Munz, D. C., Bagsby, P. G., \& Grawitch, M. J. (2009). When does time perspective matter? Self-control as a moderator between time perspective and academic achievement. Journal of Personality and Individual Differences, 46, 250-253. http://dx.doi.org/10.1016/j.paid.2008.10.007

Baron, R. M., \& Kenny, D. A. (1986). The moderator-mediator variable distinction in social psychological research: Conceptual, strategic, and statistical considerations. Journal of Personality and Social Psychology, 51, 1173-1182. http://dx.doi.org/10.1037/0022-3514.51.6.1173

Baron, S. W. (2003). Self-control, social consequences, and criminal behaviour: Street youth and the general theory of crime. Journal of Research in Crime and Delinquency, 40(4), 403-425. 
http://dx.doi.org/10.1177/0022427803256071

Bernburg, J. G., Krohn, M. D., \& Rivera, C. J. (2006). Official labeling, criminal embeddedness, and subsequent delinquency: A longitudinal test of labeling theory. Journal of Research in Crime and Delinquency, 43, 76-88. http://dx.doi.org/10.1177/0022427805280068

Bonino, S., Cattelino, E., \& Ciairano, S. (2005). Adolescents and risk. behaviours, functions, and protective factors. New York, NY: Springer.

Brendgen, M., Vitaro, F., \& Bukowski, W. M. (2000). Deviant friends and early adolescents' emotional and behavioural adjustments. Journal of Research on Adolescence, 10(2), 173-189. http://dx.doi.org/10.1207/SJRA1002_3

Brook, J. S., Brook, D. W., Balka, E. B., \& Rosenberg, G. (2006). Predictors of rebellious behaviour in childhood: Parental drug use, peers, school environment, and child personality. Journal of Addictive Diseases, 25, 77-87. http://dx.doi.org/10.1300/J069v25n02_11

Burt, C. H., Simons, R. L., \& Simons, L. G. (2006). A longitudinal test of the effects of parenting and the stability of self control: Negative evidence for the general for the general theory of crime. Journal of Criminology, 44(2), 353-396. http://dx.doi.org/10.1111/j.1745-9125.2006.00052.x

Chung, I.-J., Hill, K. G., Hawkins, J. D., Gilchrist, L. D., \& Nagin, D. S. (2002). Childhood predictors of offense trajectories. Journal of Research in Crime and Delinquency, 39(1), 60-90. http://dx.doi.org/10.1177/002242780203900103

Clark-Carter, D. (2005). Quantitative Psychological Research. A Students Handbook. Psychology Department, Staffordshire University, New Yourk.

Cohen, L., Manion, L., \& Morrison, K. (2011). Resesrch Methods in Education (7th ed.). New Yourk: Routledge.

Coie, J. D., Belding, M., \& Underwood, M. (1988). Aggression and Peer Rejection in Childhood. In B. B. Lahey, \& A. E. Kazdin (Eds.), Advances in Clinical Child Psychology (pp. 125-158). New York: Plenum. http://dx.doi.org/10.1007/978-1-4613-9829-5_3

Cretacci, M. A. (2008). A general test of self-control theory. International Journal of Offender Therapy and Comparative Criminology, 52(5), 538. http://dx.doi.org/10.1177/0306624X07308665

Dekemp, R. A. T., Vermulst, A. D. A., Finkenauer, C., Scholte, R. H. J., Overbeek, G., Rommes, E. W. M., \& Engels, R. C. (2009). Self-control and Early Adolescent Antisocial Behaviour: A Longitudinal Analysis. The journal of early adolescence, 25(4), 497-517. http://dx.doi.org/10.1177/0272431608324474

Dekovic, M. (1999). Risk and protective factors in the development of problem behaviour during adolescence. Journal of youth and adolescence, 28(6), 667-685. http://dx.doi.org/10.1023/A:1021635516758

Dekovic, M., Noom, M. J., \& Meeus, W. (1997). Expectations regarding development during adolescence: Parental and adolescent perceptions. Journal of Youth and Adolescence, 26, 253-272. http://dx.doi.org/10.1007/s10964-005-0001-7

Demuth, S., \& Brown, S. L. (2004). Family structure, family processes, and adolescent delinquency: The significance of parental absence vs. parental gender. Journal of Research in Crime \& Delinquency, 41, 58-81. http://dx.doi.org/10.1177/0022427803256236

Dishion, I, J., Nelson, E., \& Yasui, M. (2005). Predicting early adolescent gang involvement from middle school adaptation. Journal of clinical Child and Adolescent Psychology, 34(1), 62-73. http://dx.doi.org/10.1207/s15374424jccp3401_6

Dishion, T. J., \& Patterson, G. R. (2006). The development and ecology of antisocial behaviour in children and adolescents. In D. Cicchetti, \& D. J. Cohen (Eds.), Developmental psychopathology. Risk, Disorder, and Adaptation, 3 (pp. 503-541). New York, NY: Wiley.

Evans, T. D., Cullen, F. T., Burton, V. S., Dunaway, R. G., \& Benson, M. L. (1997). The social consequences of self-control: Testing the general theory of crime. Criminology, 35, 475-500. http://dx.doi.org/10.1111/j.1745-9125.1997.tb01226.x

Farrington, D. P. (2009). Conduct disorder, aggression and delinquency. In R. M. Lerner, \& L. D. Steinberg (Eds.), Handbook of adolescent psychology (pp. 683-722). New York, NY: John Wiley. http://dx.doi.org/10.1002/9780470479193.adlpsy001021

Feldman, S. S., \& Weinberger, D. A. (1994). Self restraint as a mediator of family influences on boys' delinquent behaviour: A longitudinal study. Child Development, 65(1), 195-211. http://dx.doi.org/10.2307/1131375 
Fox, K. A. (2009). Understanding gang membership, crime perpetration, and victimization among jail inmates: A test of self-control and social disorganization theories. (Unpublished doctoral dissertation), University of Florida, Gainesville.

Golchin, M. (2008). A reviow of young adult's social deviation researches in Iran. Journal of Social Science 28, 124-156.

Gorman-Smith, \& Loeber (2005) Are developmental pathways in disruptive behaviours the same for girls and boys? J Child Fam Stud, 14, 15-27. http://dx.doi.org/10.1007/s10826-005-1109-9

Gottfredson, M. R., \& Hirschi, T. (1990). A general theory of crime. Stanford University Press.

Grasmick, H. G., Bursik Jr, R. J., \& Arneklev, B. J. (1993). Reduction in drunk driving as a response to ncreased threats of shame, embarrassment, and legal sanctions. Criminology, 31(1), 41-67. http://dx.doi.org/10.1111/j.1745-9125.1993.tb01121.x

Grasmick, H. G., Tittle, C. R., Bursik, R. J., \& Arneklev, B. J. (1993). Testing the core empirical implications of Gottfredson and Hirschi's general theory of crime. Journal of Research in Crime and Delinquency, 30, 5-29. http://dx.doi.org/10.1177/0022427893030001002

Hair, J. F., Anderson, R. E., Tatham, R. L., \& Black, W. C. (1995). Multivariate data analysis (3rd ed.). New York: Macmillan Publishing Company.

Hansell, S., \& Wiatrowski, M. D. (1981). Competing conceptions of delinquent peer relations. In G. F. Jensen (Ed.), Sociology of delinquency, Current issues (pp. 93-108). Beverly Hills: Sage.

Heimer, K., \& Matsueda, R. L. (1994). Role-taking, role commitment, and delinquency: A theory of differential social control. American Sociological Review, 59, 365-390. http://dx.doi.org/10.2307/2095939

Hinshaw, S. P., Zupan, B. A., Simmel, C., Nigg, J. T., \& Melnick, S. (1997). Peer status in boys with and without attention-deficit hyperactivity disorder: Predictions from overt and covert antisocial behavior, social isolation, and authoritative parenting beliefs. Child Development, 68, 880-896. http://dx.doi.org/10.2307/1132039

Hirschi, T. (1969). Causes of delinquency. Berkeley: University of California Press.

Holtfreter, K., Reisig, M. D., Piquero, N. L., \& Piquero, A. R. (2010). Low self-control and fraud: Offending, victimization, and their overlap. Criminal Justice and Behaviour, 37, 188-204. http://dx.doi.org/10.1177/0093854809354977

Hosseini, A., \& Yekehkar, S. H. (2011). The Comparative study of family factor and delinquency in adolescents girls in Tehran Iran. Journal of social search, 4, 97-115.

Houtzager, B., \& Baerveldt, C. (1999). Just like normal: A social network study of the relation between petty crime and intimacy of adolescent friendships. Social Behaviour and Personality, 27, 177-192. http://dx.doi.org/10.2224/sbp.1999.27.2.177

Jessor, R., Turbin, M. S., \& Costa, F. M. (1998). Risk and protection in successful outcomes among disadvantaged adolescents. Applied Developmental Science, 2, 194-208. http://dx.doi.org/10.1207/s1532480xads0204_3

Jessor, R., Turbin, M. S., Costa, F. M., Dong, Q., Zhang, H., \& Wang, C. (2003). Adolescent problem behaviour in China and the United States: A cross-national study of psychosocial protective factors. Journal of Research on Adolescence, 13, 329-360. http://dx.doi.org/10.1111/1532-7795.1303004

Jessor, R., Van Den Bos, J., Vanderryn, J., Costa, F. M., \& Turbin, M. (1995). Protective factors in adolescent problem behaviour: Moderator effects and developmental change. Developmental Psychology, 31, 923-933. http://dx.doi.org/10.1037/0012-1649.31.6.923

Jose, E. P. (2008). Welcome to the Moderation/Mediation Help Centre (2nd ed.). School of Psychology, Victoria University of Wellington, Wellington.

Kandel, D. B. (1990). Parenting styles, drug use, and children's adjustment in families of young adults. Journal of Marriage and Family, 52(1), 183-196. http://dx.doi.org/10.2307/352849

Kiesner, J., \& Massimiliano, P. (2005). Differences in the relations between antisocial behaviour and peer acceptance across contexts and across adolescence. Child Development, 76, 1278-1293. http://dx.doi.org/10.1111/j.1467-8624.2005.00850.x

Kim, S., \& Brody, G. H. (2005). Longitudinal pathways to psychological adjustment among Black youth living 
in single-parent households. Journal of Family Psychology, 19(2), 305-313. http://dx.doi.org/10.1037/0893-3200.19.2.305

Lipsey, M. W., \& Derzon, J. H. (1998). Predictors of violent or serious delinquency in adolescence or early adulthood: A synthesis of longitudinal research. In R. Loeber, \& D. P. Farrington (Eds.), Serious and violent juvenile offenders: Risk factors and successful interventions (pp. 86-105). Thousand Oaks, CA: Sage.

Moffitt, T. E., Arsenault, L., Belsky, D., Dickson, N., Hancox, R. J., Harrington, H., \& Caspi, A. (2011). A gradient of childhood self-control predicts health, wealth and public safety, Proceedings of the National Academy of Sciences of the United States of America, 10, 2693-2698. http://dx.doi.org/10.1073/pnas.1010076108

Mohammadiasl, A. (2006). The dysfunction of family, school and peer -group and their effects on juvenile delinquency. Iran: Haghshenas.

Moss, H., Lynch, K., \& Hardie, T. (2003). Affiliation with deviant peers among children of substance dependent fathers from pre-adolescence into adolescence: Associations with problem behaviours. Drug and Alcohol Dependence, 71, 117-125. http://dx.doi.org/10.1016/S0376-8716(03)00073-5

Mrug, S., Hoza, B., \& Bukowski, W. M. (2004). Choosing or being chosen by aggressive disruptive peers: Do they contribute to children's externalizing and internalizing problems? Journal of Abnormal Child Psychology, 32, 53-65. http://dx.doi.org/10.1023/B:JACP.0000007580.77154.69

Muraven, M., \& Baumeister, R. F. (2000). Self-regulation and depletion of limited resources: Does self-control $\begin{array}{lllll}\text { resemble a muscle? } & \text { Psychological }\end{array}$ http://dx.doi.org/10.1037/0033-2909.126.2.247

Murry, V. M., \& Brody, G. H. (1999). Self-regulation and self-worth of black children reared in economically stressed, rural, single mother-headed families: The contribution of risk and protective factors. Journal of Family Issues, 20(4), 458-484. http://dx.doi.org/10.1177/019251399020004003

Nagin, D., \& Tremblay, R. E. (1999). Trajectories of boys' physical aggression, opposition, and hyperactivity on the path to physically violent and non-violent juvenile delinquency. Child Development, 70(5), 1181-1196. http://dx.doi.org/10.1111/1467-8624.00086

National Center for Education Statistics. (2007). Institute of Education Sciences, U.S. Department of Education, Washington, DC.

National Center for Education Statistics. (2010). Institute of Education Sciences, U.S. Department of Education, Washington, DC.

Nobles, M. R., Cramer, R. J., \& Kerecher, G. A. (2012). Understanding how some victims become perpetrators: Self-control as a moderator.

Padilla-Walker, L. M., Been, R. A., \& Hiseh, A. L. (2011). The role of parenting and personal characteristics on deviant peer association among European American and Latino adolescents. Journal of Children and Youth Services Review, 33, 234-242.

Pallant, J. (2011). SPSS Survival Manual: A Step by Step guide to data analysis using SPSS (4th ed.). Australia: Allen \& Unwin.

Paternoster, R., \& Brame, R. (1997). Multiple routes to delinquency? A test of developmental and general theories of crime. Criminology, 35, 49-84. http://dx.doi.org/10.1111/j.1745-9125.1997.tb00870.x

Patterson, G. R., DeBaryshe, B. D., \& Ramsey, E. (1989). A developmental perspective on antisocial behaviour. American Psychologist, 44, 329-335. http://dx.doi.org/10.1037/0003-066X.44.2.329

Patterson, G. R., Dishion, T. J., \& Yoerger, K. (2000). Adolescent growth in new forms of problem behaviour: Macro- and micro- peer dynamics. Prevention Science, 1(1), 3-13. http://dx.doi.org/10.1023/A:1010019915400

Peterson, C. (2004). Looking forward through childhood and adolescence. Frenchs Forest, NSW: Pearson Education Australia.

Rezayi, S., Kharazi, K., Hejazi, E., \& Afrooz, K. (2007). A study of the effect of familial, social and personal-cognitive characteristic of individuals in developing juvenile delinquency. Journal of aplied psychology, 1(4), 6-13.

Santrock, J. W. (1996). Adolescence. Madison. USA: Brown and Benchmark. 
Schreck, C. J., Wright, R. A., \& Miller, J. M. (2002). A study of individual and situational antecedents of violent victimization. Justice Quarterly, 19, 159-180. http://dx.doi.org/10.1080/07418820200095201

Snyder, J., Edwards, P., McGraw, K., Kilgore, K., \& Holton, A. (1994). Escalation and reinforcement on mother-child conflict: Social processes associated with development of physical aggression. Development and Psychopathology, 6, 305-321. http://dx.doi.org/10.1017/S0954579400004600

Sobotkova, V., Batny, M., Jelinek, M., \& Hrdlic, M. (2012). Antisocial behaviour in adolescence: Typology and relation to family context. Journal of Early Adolescence, $x x(\mathrm{x}), 1-25$.

Stewart, E. A., Elifson, K. W., \& Sterk, C. E. (2004). Integrating the general theory of crime into an exploration of violent victimization among female offenders. Justice Quarterly, 21, 159-181. http://dx.doi.org/10.1080/07418820400095771

Stouthamer-Loeber, M., Loeber, R., Wei, E., Farrington, D. P., \& Wikström, P.-O. (2002). Risk and promotive effects in the explanation of persistent serious delinquency in boys. Journal of Consulting and Clinical Psychology, 70, 111-123. http://dx.doi.org/10.1037/0022-006X.70.1.111

Sussman, S. (2013). A life span developmwnt -stage approach to tobacco and other drug abuse prevention.

Tittle, C. R., Ward, D. A., \& Grasmick, H. G. (2003). Gender, age, and crime/deviance: A challenge to self-control theory. Journal of Research in Crime and Delinquency, 40(4), 426-453. http://dx.doi.org/10.1177/0022427803256074

Vaillancourt, T., Hymel, S., \& McDougall, P. (2003). Bullying is power: Implications for school-based intervention strategies. Journal of Applied School Psychology, 19, 157-176. http://dx.doi.org/10.1300/J008v19n02_10

Vazsonyi, A. T., Pickering, L. E., Junger, M., \& Hessing, D. (2001). An empirical test of a general theory of crime: A four-nation comparative study of self-control and the prediction of deviance. Journal of Research in Crime and Delinquency, 38, 91-131. http://dx.doi.org/10.1177/0022427801038002001

Vazsonyi, A. T., Wittekind, J. E. C., Belliston, L. M., \& Van Loh, T. D. (2004). Extending the general theory of crime to the East: Low self-control in Japanese adolescents. Journal of Quantitative Criminology, 20(3), 189-201. http://dx.doi.org/10.1023/B:JOQC.0000037731.28786.e3

Vitaro, F., Brendgren, M., \& Tremblay, R. E. (2000). Influence of deviant friends on delinquency: Searching for moderator variables. Journal of Abnormal Child Psychology, 28, 313-325. http://dx.doi.org/10.1023/A:1005188108461

Vitaro, F., Gagnon, C., \& Tremblay, R. E. (1990). Predicting stable peer rejection from kindergarten to grade one. Journal of Clinical Child Psychology, 19, 257-264. http://dx.doi.org/10.1207/s15374424jccp1903_9

Vitaro, F., Tremblay, R. E., Kerr, M., Pagani, L., \& Bukowski, W. M. (1997). Disruptiveness, friends' characteristics, and delinquency in early adolescence: A test of two competing models of development. Child Development, 68, 676-689. http://dx.doi.org/10.2307/1132118

Ward, J. T., Gibson, C. L., Boman, J., \& Leite, W. L. (2010). Assessing the validity of the retrospective behavioural self-control scale. Is the general theory of crime stronger than evidence suggests? Criminal Justice and Behaviour, 37, 336-357. http://dx.doi.org/10.1177/0093854809359673

West, S. G., Aiken, L. S., \& Krull, J. L. (1996). Experimental personality designs: Analyzing categorical by continuous variable interactions. Journal of Personality, 64, 1-48. http://dx.doi.org/10.1111/j.1467-6494.1996.tb00813.x

Windle, M. (1999). Alcohol use among adolescents. Thousand Oaks, CA: Sage.

Wright, R., John, L., Livingstone, A. M., Shepherd, N., \& Duku, E. (2007). Effects of school-based interventions on secondary school students with high and low risks for antisocial behaviour. Canadian Journal of School Psychology, 22(1), 32-49. http://dx.doi.org/10.1177/0829573507301249

\section{Copyrights}

Copyright for this article is retained by the author(s), with first publication rights granted to the journal.

This is an open-access article distributed under the terms and conditions of the Creative Commons Attribution license (http://creativecommons.org/licenses/by/3.0/). 